\title{
The participation of ribosome-UDP-GalNAc complex in the initiation of protein glycosylation in vitro
}

\author{
Anna Paszkiewicz-Gadek ${ }^{\bowtie}$, Halina Porowska and Andrzej Gindzieński \\ Department of General and Organic Chemistry, Institute of Chemistry Medical Academy, \\ 15-230 Biatystok 8, Poland
}

Received: 12 August, 1999; revised: 23 March, 2000; accepted: 5 April, 2000

Key words: ribosome, UDP-GalNAc, glycosylation, UDP-GalNAc-transferase, apomucin

\begin{abstract}
The gastric epithelial cells ribosome-UDP-GalNAc complex is a donor of UDPGalNAc as the substrate for $N$-acetylgalactosaminyltransferase, which catalyse the transfer of GalNAc residue to the polypeptide, existing on polysomes. It was observed that the deglycosylated porcine mucin and synthetic peptide (PTSSPIST) can be also glycosylated with participation of $\mathrm{N}$-acetylgalactosaminyltransferase and ribosomeUDP-GalNAc complex. The probability of the ribosome-UDP-GalNAc complex as an intermediate in the O-glycosylation is considered.
\end{abstract}

Glycoprotein biosynthesis, especially its sequential O-glycosylation, has been a matter of investigations for many years. In contrast to N-glycosylation, O-glycosylation does not begin with the transfer of oligosaccharide from a dolichol precursor, but with the addition of a single monosaccharide from the nucleotide substrate to acceptors. In the case of mucintype glycoproteins, GalNAc is transferred to the hydroxyl of some serine or threonine residues of the mucin protein backbone. The polypeptide $\mathrm{N}$-acetylgalactosaminyltransferase family (pp-GalNAc-transferase, EC 2.4.1.41) is involved in the initiation of
O-glycosylation. The site of the subcellular compartment where O-glycosylation is initiated is still controversial (ER, proximal Golgi, intermediate ER-Golgi, beyond ER-Golgi in Golgi apparatus) [1-8] and may depend on the type of pp-GalNAc-transferases involved.

In a previous study we demonstrated the formation of stable complexes between active ribosomes and nucleotide carbohydrates, which have the ability to form the substrates for glycosyltransferases [9-11]. These results encouraged us to test the possibility of initiating O-glycosylation of polypeptide existing on polysome and exogenous peptides (synthetic

\footnotetext{
${ }^{{ }}$To whom correspondence should be addressed. Tel: (48 85) 742 2059; fax: (48 85) 742 4907; e-mail: zachemog@amb.ac.bialystok.pl
}

Abbreviations: GalNAc, $N$-acetyl-D-galactosamine; DTT, dithiothreitol; TFMSA, trifluoromethane sulfonic acid; ER, endoplasmic reticulum; PTSSPIST, synthetic I peptide. 
or apomucin preparation), as acceptors in glycosyltransferase reaction in vitro, using UDP- $N$-acetylgalactosamine-ribosome complex as a carbohydrate donor. In our earlier investigations we demonstrated the formation of Dol-P-P-(GlcNAc) ${ }_{2}$ with UDP-GlcNAc-ribosome complex. The oligosaccharide from Dol-P-P-(GlcNAc) $)_{2}$ was incorporated in vitro into the polypeptide synthesized on polysomes [12].

\section{MATERIALS AND METHODS}

Materials. UDP-N-acetyl-D-[1- $\left.{ }^{14} \mathrm{C}\right]$ galactosamine $(56 \mathrm{mCi} / \mathrm{mmol})$ and $\left[\mathrm{U}^{14} \mathrm{C}\right]$ leucine (300 $\mathrm{mCi} / \mathrm{mmol}$ ) were purchased from Amersham; UDP-[1- $\left.{ }^{3} \mathrm{H}(\mathrm{N})\right]-N$-acetyl-D-galactosamine (14.7 $\mathrm{Ci} / \mathrm{mmol}$ ) was from DuPont NEN; all other chemicals were analytical grade purity from commercial sources.

Ribosomes, $\left[{ }^{14}\right.$ Clleucyl-tRNA and elongation factors were prepared as described previously [13]. The purity of ribosomes was tested by means of an electronic microscope and by the ratios: $\mathrm{A}_{260} / \mathrm{A}_{280}, \mathrm{~A}_{260} / \mathrm{A}_{235}$, $\mathrm{RNA} /$ protein and the phospholipid content [14]. The biological activity of the ribosomes was estimated in test of $\left[{ }^{14} \mathrm{C}\right]$ leucine incorporation into proteins [13]. The ribosome preparation was admitted as free from reticulum membranes therefore free from glycosyltransferases. Protein contents were determined by the Lowry et al. method [15] using bovine serum albumin as a standard. All procedures were performed at $2-4^{\circ} \mathrm{C}$.

Preparation of ribosome-UDP-N-acetyl${ }^{\mathbf{1 4}}$ Clgalactosamine complex. The reaction mixture in a total volume of $200 \mu \mathrm{l}$, containing: ribosomal suspension ( $3 \mathrm{mg}$ ), UDP$\left[{ }^{14} \mathrm{C}\right]$ GalNAc $(0.5 \mu \mathrm{Ci})$ and $50 \mathrm{mM}$ Tris/HCI buffer, $\mathrm{pH}$ 7.0, was incubated for $30 \mathrm{~min}$ at $37^{\circ} \mathrm{C}$. This ribosome-nucleotide complex was then isolated according to our previously described method [12] and immediately used for further experiments.
Glycosylation of the peptide chain existing on polysomes

(a) With the use of UDP-GalNAc. The incubation mixture consisted of ribosomes purified from epithelial gastric mucosa $(3 \mathrm{mg})$, UDP- $\left[{ }^{14} \mathrm{C}\right]$ GalNAc (9.2 nmoles), GalNActransferase preparation, $5 \mathrm{mM} \mathrm{MnCl}_{2}$ and 50 $\mathrm{mM}$ imidazole/ $\mathrm{HCl}$ buffer, $\mathrm{pH}$ 7.2, was incubated at $37^{\circ} \mathrm{C}$ for $30 \mathrm{~min}$ in a total volume of 1 $\mathrm{ml}$. The cooled mixture was then centrifuged for $2.5 \mathrm{~h}$ at $105000 \times \boldsymbol{g}$ on the sucrose gradient [13]. The translocation of glycosylated polypeptide from $\mathrm{A}$ to $\mathrm{P}$ site of elongation factor was performed in the following way: the ribosome pellet was suspended in $0.4 \mathrm{ml}$ of a solution containing: $50 \mathrm{mM}$ Tris/ $\mathrm{HCl}, \mathrm{pH} 8.0,2$ $\mathrm{mM}$ dithiothreitol, $6 \mathrm{mM} \mathrm{MgCl}_{2}, 80 \mathrm{mM}$ $\mathrm{NH}_{4} \mathrm{Cl}, 0.2 \mathrm{mM}$ GTP-MgCl 2 then $60 \mu \mathrm{g}$ of the elongation factor EF-2 was added and incubated for $30 \mathrm{~min}$ at $37^{\circ} \mathrm{C}$. Then the sample was cooled in an ice bath, mixed with puromycin $(1 \mu \mathrm{mol})$ and $\mathrm{NH}_{4} \mathrm{Cl}(10 \mu$ moles $)$, and the incubation was continued at $37^{\circ} \mathrm{C}$ for $30 \mathrm{~min}$. The reaction with puromycin was terminated by the addition of cooled $0.1 \mathrm{M}$ sodium acetate solution, $\mathrm{pH}$ 5.5. The GalNAc-containing polypeptide released from ribosomes was extracted [16] and its radioactivity was measured in scintillation liquid (Ultima Gold).

(b) With the use of ribosome-UDPGalNAc complex. The O-glycosylation reaction was performed in the same conditions as above, except that the ribosome-UDP- $\left[{ }^{14} \mathrm{C}\right]$ GalNAc complex (composed of $3 \mathrm{mg}$ ribosomes and 62 pmoles UDP-[ $\left.{ }^{14} \mathrm{C}\right]$ GalNAc) was added instead of UDP- $\left[{ }^{14} \mathrm{C}\right]$ GalNAc. Next steps: isolation of ribosomes, translocation of glycosylated polypeptide, release and extraction of polypeptide from ribosomes were carried out as described in point (a).

\section{Preparation and purification of mucus glycoproteins}

Gastric mucus was obtained in a procedure elaborated in our laboratory [17]. Mucin ex- 
tract (in $6 \mathrm{M}$ urea) was purified (by gel exclusion chromatography) twice on Sepharose CL-2B and on Sephacryl S-500 columns. Both columns were equilibrated and eluted with 6 $\mathrm{M}$ urea solution in borate buffer, $\mathrm{pH}$ 7. Fractions containing the mucin were identified by the phenol-sulfuric acid method [18], pooled, dialyzed against water and tested for purity by SDS/PAGE.

Deglycosylation of purified mucin. The purified mucin was reduced and $S$-carboxymethylated according to Thornton et al. [19], then digested with pronase and glycoprotein fragments were separated on a Sephacryl S-500 column. The deglycosylation was performed in TFMSA/anisole mixture (10:1, v/v), according to Raju \& Davidson [20]. After oxidation with periodate and $\beta$-elimination [21], the samples were treated as previously described with TFMSA/ anisole.

\section{Purification of UDP-GalNAc: polypeptide $\mathrm{N}$-acetylgalactosaminyltransferase}

pp-GalNAc-transferase (EC 2.4.1.41) was isolated from the porcine gastric mucusa according to the procedure previously described [22].

\section{Glycosylation of the synthetic peptide or porcine apomucin}

(a) With the use of UDP-GalNAc. A standard assay mixture contained $0.1 \mathrm{M}$ imidazole/HCl buffer, $\mathrm{pH} 7.2,10 \mathrm{mM} \mathrm{MnCl}_{2}, 4$ $\mathrm{mM}$ dithiothreitol, $0.5 \%$ Triton $\mathrm{X}-100,0.1$ $\mathrm{mg} / 0.1 \mathrm{ml}$ of purified GalNAc-transferase preparation, $1 \mathrm{mg}$ of apomucin or $0.3 \mathrm{mg}$ of synthetic peptide, $0.1 \mathrm{nmol}$ UDP- $\left[{ }^{3} \mathrm{H}\right]$ GalNAc and 30 nmoles of UDP-GalNAc in a final volume of $0.2 \mathrm{ml}$. Samples were incubated at $37^{\circ}$ for $60 \mathrm{~min}$. The reaction was stopped by the addition of $100 \mu \mathrm{l}$ of $25 \mathrm{mM}$ EDTA, and the mixture was applied to a column of Dowex 1-X $8(2 \mathrm{ml})$, in acetate form. The column was washed with $10 \mathrm{ml}$ of $20 \mathrm{mM}$ sodium acetate
[23]. From the $1 \mathrm{ml}$ fractions aliquots $(0.5 \mathrm{ml})$ were taken, mixed with $5 \mathrm{ml}$ of scintillation liquid and submitted for radioactivity counting.

(b) With the use of ribosome-UDPGalNAc complex. This assay mixture was the same as above except UDP-GalNAc was replaced with ribosome-UDP-GalNAc complex prepared as previously described (see Methods). The ribosome-UDP-GalNAc complex (obtained from $2 \mathrm{mg}$ of mucosa ribosomes and 37.2 nmoles UDP-[ $\left[{ }^{3} \mathrm{H}\right]$ GalNAc) was suspended in $120 \mu \mathrm{l}$ of $0.05 \mathrm{M}$ Tris/HCl buffer, $\mathrm{pH} 7.4 ; 20 \mu \mathrm{l}$ of suspension was submitted for counting the radioactivity bound to the ribosomes, the rest of the sample with ribosome-UDP-GalNAc was used for glycosylation reaction under the same conditions as described above in (a). After incubation, EDTA was added to the assay mixture and next applied to a column $(0.8 \mathrm{~cm} \times 12 \mathrm{~cm})$ of Sephadex G-50 (fine), equilibrated with $0.1 \mathrm{M}$ $\mathrm{NaCl}$ containing $0.02 \% \mathrm{NaN}_{3}$. The column was eluted with $0.1 \mathrm{M} \mathrm{NaCl}$. The $0.5 \mathrm{ml}$ aliquot of each $1 \mathrm{ml}$ fraction was mixed with $5 \mathrm{ml}$ of scintilation liquid and submitted for radioactivity counting. The radiolabeled apomucin or synthetic peptide was eluted in void volume of the column, and the next fractions contained unbound radiolabeled sugar.

\section{RESULTS AND DISCUSSION}

In the first step of our experiments we compared the binding of UDP-Gal[ $\left.{ }^{3} \mathrm{H}\right] \mathrm{NAc}$ to the ribosomes, isolated from different tissues "specialized" in the biosynthesis of $\mathrm{O}$ - and $\mathrm{N}$-glycoproteins (gastric mucosa and liver, respectively). The obtained results showed, that $1 \mathrm{mg}$ of ribosome preparation from gastric mucosa binds 9.2 nmoles of UDP-[ $\left.{ }^{3} \mathrm{H}\right] \mathrm{GalNAc}$, in contrast to liver ribosomes (1.6 nmoles UDP-GalNAc), what demonstrates the high specificity of gastric ribosomes to this substrate (Table 1). These results suggest the pos- 
Table 1. The binding of UDP-[ ${ }^{14}$ C]GalNAc to ribosomes

\begin{tabular}{lccccc}
\hline & \multicolumn{2}{c}{ Amount of UDP-[ ${ }^{14}$ C]GalNAc (nmoles) } & \multicolumn{2}{c}{ Bound nucleotide } \\
\cline { 2 - 4 } Source of ribosomes & \multirow{2}{*}{ initial } & \multicolumn{2}{c}{ bound to ribosomes } & \multirow{2}{*}{$\begin{array}{c}\text { nmoles } / \mathrm{mg} \\
\text { ribosomes }\end{array}$} & $\%$ \\
\cline { 3 - 5 } & & sample & control & & \\
\hline Mucosa (0.25 mg) & 180 & 2.8 & 0.5 & 9.2 & 1.27 \\
Liver (0.5 mg) & 180 & 1.0 & 0.2 & 1.6 & 0.44 \\
\hline
\end{tabular}

In the control experiments the ribosomes were inactivated at $100^{\circ} \mathrm{C}$ for $2 \mathrm{~min}$, other conditions as described in Materials and Methods.

sibility of the ribosome-UDP-GalNAc complex participation in the effective initiation of protein of O-glycosylation in gastric mucosa cells.

The results of glycosylation of nascent polypeptide with ribosome-UDP-GalNAc scent peptide in the case of the glycosylation with the complex ribosome-UDP-GalNAc, because UDP-GalNAc content in the complex was much lower than the concentration of free UDP-GalNAc. These results demonstrate that the GalNAc, from the ribosome-UDP-

Table 2. Glycosylation of nascent polypeptide with pp-GalNAc-transferase and two sources of UDP-GalNAc

\begin{tabular}{|c|c|c|c|c|c|}
\hline \multirow{2}{*}{$\begin{array}{l}\text { UDP- }\left[{ }^{14} \mathrm{C}\right] \text { GalNAc source to } \\
\text { GalNAc-transferase reaction }\end{array}$} & \multicolumn{2}{|c|}{$\begin{array}{c}\text { Amount of } \\
\text { UDP- }\left[{ }^{14} \mathrm{C}\right] \text { GalNAc }\end{array}$} & \multicolumn{3}{|c|}{$\begin{array}{c}\left.{ }^{14} \mathrm{C}\right] \text { GalNAc bound to nascent } \\
\text { polypeptide (pmoles) }\end{array}$} \\
\hline & $\begin{array}{c}\text { initial } \\
\text { (nmoles) }\end{array}$ & $\begin{array}{l}\text { in complex } \\
\text { (pmoles) }\end{array}$ & $\begin{array}{c}\text { with } \\
\text { transferase }\end{array}$ & $\begin{array}{c}\text { without } \\
\text { transferase }\end{array}$ & net value \\
\hline UDP-GalNAc-ribosome complex & - & 62 & 16 & 2 & 14 \\
\hline UDP-GalNAc free and ribosomes & 9.2 & - & 15 & 5 & 10 \\
\hline
\end{tabular}

The amount of epithelial gastric ribosomes was the same in both cases. For details, see Materials and Methods. The experiments were performed by following steps: 1 , formation of UDP- $\left[{ }^{14} \mathrm{C}\right]$ GalNAc-ribosome complex; 2, O-glycosylation of nascent peptide with or without GalNAc-transferase: a, in the UDP-GalNAc-ribosome complex; b, in the free ribosomes; 3 , isolation of glycosylated polypeptides.

complex, as well as, with UDP-GalNAc as substrates tested with partially purified preparations of pp-GalNAc-transferase are presented in Table 2. These results show that the greater amount of sugar was incorporated into the na-
GalNAc complex can be transferred onto the nascent polypetide by the pp-GalNActransferase.

The synthetic peptide (PTSSPIST) or free of carbohydrates apomucin preparations were

Table 3. The O-glycosylation of peptides by ribosome-UDP-[ $\left.{ }^{3} \mathrm{H}\right] \mathrm{GalNAc}$ complex as a donor of GalNAc for pp-GalNAc-transferase

\begin{tabular}{|c|c|c|c|}
\hline Acceptor peptide & $\begin{array}{l}\text { UDP- }\left[{ }^{3} \mathrm{H}\right] \text { GalNAc as ribosome } \\
\text { complex (pmoles) }\end{array}$ & $\begin{array}{l}{\left[{ }^{3} \mathrm{H}\right] \text { GalNAc incor- }} \\
\text { porated (pmol) }\end{array}$ & $\begin{array}{c}{\left[{ }^{3} \mathrm{H}\right] \mathrm{GalNAc} \text { pmol/ }} \\
\text { mg acceptor }\end{array}$ \\
\hline PTSSPIST & 128 & 2.5 & 8.3 \\
\hline Apomucin & 100 & 4.5 & 4.5 \\
\hline
\end{tabular}

The reaction was performed in a mixture containing $0.3 \mathrm{mg}$ of PTSSPIST peptide or $1 \mathrm{mg}$ of apomucin,100 $\mu \mathrm{l}$ pp-GalNActransferase preparation and ribosome-UDP- $\left[{ }^{3} \mathrm{H}\right]$ GalNAc complex, and incubated at $37^{\circ} \mathrm{C}$ for 60 min (in 3 samples). For details see Materials and Methods. In control experiments only GalNAc-trasferase was omitted. The obtained values of incorporated $\left[{ }^{3} \mathrm{H}\right]$ GalNAc were at the background level. 
used as carbohydrate acceptors (Table 3). The results show that, chemically synthesized peptide was glycosylated by ribosome-UDPGalNAc complex as a carbohydrate donor to much higher extent as compared to apomucin preparation (Table 3). This difference in extent of glycosylation depends upon amino-acid composition of the peptide acceptors: the apomucin consists of only $30 \%$ of hydroxyl amino acids but peptide PTSSPIST $-62.5 \%$ [22].

It is very reasonable to suppose, that in vivo, ribosomes can also participate in the O-glycosylation processes. Some authors suggest that the positioning of pp-GalNAc-transferase on, or near the ribosome might promote the efficient glycosylation of Ser/Thr residues, irrespective of amino-acid sequences adjacent to the glycosylated site [24]. It is also reasonable to assume that ribosomes can play an active or passive intermediate role in the early event in mucin O-glycosylation. Ribosomes can accumulate active forms of carbohydrates, forming complex closely located to glycosyltransferases, connected with the bilayer structure of rough endoplasmic reticulum. Cotranslational O-glycosylation seems to be theoretically plausible; singly glycosylated regions of protein can be more extended, created more accessible conformation for the subsequent glycosylation [25].

Summarizing, it may be suggested that the epithelial ribosome-UDP-GalNAc complex can play an intermediate role in the initiation of the O-glycosylation process of mucin-type glycoproteins.

\section{R E F E R E N C E S}

1. Abeijon, C. \& Hirschberg, C.B. (1987) Subcellular site of synthesis of the $N$-acetylgalactosamine ( $\alpha 1-0)$ serine (or threonine) linkage in rat liver. J. Biol. Chem. 262, 4153-4159.

2. Elhammer, A. \& Kornfeld, S. (1984) Two enzymes involved in the synthesis of O-linked oli- gosaccharides are localized on membranes of different densities in mouse lymphoma BW5147 cells. J. Cell Biol. 98, 327-331.

3. Piller, V., Piller, F. \& Fukuda, M. (1990) Biosynthesis of truncated $O$-glycans in the T cell line Jurkat. Localization of O-glycan initiation. J. Biol. Chem. 265, 9264-9271.

4. Roth, J., Wang, Y., Eckhardt, A.E. \& Hill, R.L. (1994) Subcellular localization of the UDP- $N$ acetyl-D-galactosamine: polypeptide $N$-acetylgalactosaminyltransferase-mediated O-glycosylation reaction in the submaxillary gland. Proc. Natl. Acad. Sci. U.S.A. 91, 8935-8939.

5. Sweizer, A., Clausen, H., van Meer, G. \& Hauri, H.P. (1994) Localization of glycans initiation, sphingomyelin synthesis, and glycosylceramide synthesis in Vero cells with respect to the endoplasmic reticulum - Golgi intermediate compartment. J. Biol. Chem. 269, 4035-4041.

6. Palzelt, C. \& Weber, B. (1986) Early O-glycosidic glycosylation of proglucagon in pancreatic islets: An unusual type of prohormonal modification. EMBO J. 5, 2103-2108.

7. Perez-Vilar, J., Hidalgo, J. \& Velasco, A. (1991) Presence of terminal $N$-acetylgalactosamine residues in subregions of the endoplasmic reticulum is influenced by cell differentiation in culture. J. Biol. Chem. 266, 23967-23976.

8. Ellinger, A. \& Pavelka, M. (1992) Subdomains of rough endoplasmic reticulum in colon goblet cells of the rat: Lectin-cytochemical characterization. J. Histochem. Cytochem. 40, 919-930.

9. Kopacz-Jodczyk, T. \& Gałasiński, W. (1987) The binding of decomposition products of UDP-galactose to the microsomes and polyribosomes isolated from rat liver. Biochem. Med. Metab. Biol. 38, 149-155.

10. Kopacz-Jodczyk, T., Paszkiewicz-Gadek, A. \& Gałasiński, W. (1988) The attachment of UDP-hexosamines to the ribosomes isolated 
from rat liver. Biochem. Med. Metab. Biol. 39, 290-295.

11. Paszkiewicz-Gadek, A., Gindzieński, A. \& Porowska, H. (1996) Nucleotide-sugar binding to ribosomes. Comparison of affinity and capacity of gastric mucosa and liver ribosomes to sugar-nucleotides. Ann. Acad. Med. Bialostocensis 41, 305-315.

12. Paszkiewicz-Gadek, A., Porowska, H. \& Gałasiński, W. (1992) The participation of ribosomes in protein glycosylation. Interaction of the ribosome-UDP- $N$-acetylglucosamine complex with dolichol phosphate. Acta Biochim. Polon. 39, 251-264.

13. Jabłonowska, K., Kopacz-Jodczyk, T., Niedźwiecka, J. \& Gałasinski, W. (1983) Isolation and characterization of elongation factor EF-2 from Guerin tumour. Acta Biochim. Polon. 30, 381-389.

14. Petermann, M.L. (1964) The Physical and Chemical Properties of Ribosomes; pp. 63, American Elsevier, New York.

15. Lowry, O.H., Rosebrough, N.J., Farr, A.L. \& Randall, R.J. (1951) Protein measurement with the Folin phenol reagent. J. Biol. Chem. 193, 265-275.

16. Leder, P. \& Bursztyn, H. (1966) Initiation of protein synthesis. II. A convenient assay for the ribosome-dependent synthesis of $\mathrm{N}$-for-

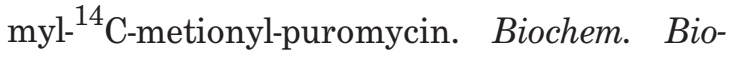
phys. Res. Commun. 25, 233-238.

17. Gindzieński, A. \& Zwierz, K. (1987) Isolation and fractionation of human gastric mucus gel. Biomed. Biochim. Acta 46, 165-176.

18. Dubois, M., Gilles, K.A., Hamilton, J.K., Rebers, P.A. \& Smith, F. (1956) The phenolsulfuric acid reaction for carbohydrates. Anal. Chem. 28, 350-356.
19. Thornton, D.J., Howard, M., Devine, P.L. \& Sheehan, J.K. (1995) Methods for separation and deglycosylation of mucin subunits. Anal. Biochem. 227, 162-167.

20.Raju, T.S. \& Davidson, E.A. (1994) New approach towards deglycosylation of sialoglycoproteins and mucins. Biochem. Mol. Biol. Int. 34, 943-954.

21. Gerken, J.A., Gupta, R. \& Jentoft, N. (1992) A novel approach for chemically deglycosylating O-linked glycoproteins. The deglycosylation of submaxillary and respiratory mucins. Biochemistry 31, 639-648.

22. Porowska, H., Paszkiewicz-Gadek, A., Gindzieński, A. (1999) Activity of partially purified UDP- $N$-acetyl- $\alpha$-D-galactosamine: polypeptide $N$-acetylgalactosaminyltransferase with different peptide acceptors. Acta Biochim. Polon. 46, 365-370.

23. Wang, Y., Abemethy, J.L, Eckhardt, A.E. \& Hill, R.L. (1992) Purification and characterization of a UDP-GalNAc:polypeptide $N$-acetylgalactosaminyl-transferase specific for glycosylation of treonine residues. J. Biol. Chem. 267, 12709-12716.

24. Mendicino, J. \& Sangadala, S. (1998) Purification and charcterization of UDP-GalNAc: polypeptide $\quad \mathrm{N}$-acetylgalactosaminyltransferase from swine trachea epithelium. Mol. Cell. Biochem. 185, 135-145.

25. Gerken, T.A., Owens, C.L. \& Pasumarthy, M. (1998) Site-specific core 1-O-glycosylation pattern of the porcine submaxillary gland mucin tandem repeat. Evidence for the modulation of glycan length by peptide sequence. J. Biol. Chem. 273, 26580-26588. 